\title{
TEMPERATURE MEASUREMENTS IN A TEMPERATE GLACIER
}

\author{
By W. D. Harrison* \\ (Geophysics Program, University of Washington, Seattle, Washington 98195, U.S.A.)
}

\begin{abstract}
Abstracr. Temperatures have been measured at two sites in a temperate glacier (Blue Glacier, Washington, U.S.A.) to depths of 192 and $76 \mathrm{~m}$. The accuracy, which varies between about 0.002 and $0.005 \mathrm{deg}$, is about an order of magnitude better than previously obtained. Except near the surface, temperatures vary linearly with depth but are in disagreement with the simplest model of a temperate glacier, being about 0.02 deg colder near the surface and 0.04 deg colder at $19^{2} \mathrm{~m}$ depth.
\end{abstract}

RÉsumé. Mesures de températures dans un glacier tempéré. Les températures ont été mesurées en deux sites d'un glacier tempéré (Blue Glacier, Washington, U.S.A.) à des pronfondeurs de $19^{2}$ et de $76 \mathrm{~m}$. La précision, qui varie entre 0,002 et $0,005 \mathrm{deg}$, est d'un ordre de grandeur meilleur que celle obtenue jusqu'ici. Excepté près de la surface, les températures varient linéairement avec l'épaisseur mais sont en désaccord avec le modèle le plus simple d'un glacier tempéré; elles sont d'environ 0,02 deg trop froides près de la surface et de 0,04 deg trop froides à $192 \mathrm{~m}$ de profondeur.

Zusammenfassung. Temperaturmessungen in einem temperierten Gletscher. An zwei Stellen in einem temperierten Gletscher (Blue Glacier, Washington, U.S.A.) wurden Temperaturen in $19^{2} \mathrm{~m}$ und $76 \mathrm{~m}$ Tiefe gemessen. Die Genauigkeit, die zwischen $\pm 0,002$ und $\pm 0,005$ deg schwankt, ist etwa eine Grössenordnung besser als bei früheren Messungen. Ausser in Oberflächennähe ändert sich die Temperatur linear mit der Tiefe, weicht jedoch vom einfachsten Modell eines temperierten Gletschers um etwa 0,02 deg nahe der Oberfäche und um 0,04 deg in $192 \mathrm{~m}$ Tiefe nach unten ab.

\section{INTRODUCTION}

Although there is nothing new about the concept of temperate ice, there has been a recent revival of interest in its basic physics and chemistry (Nye and Frank, 1973; Lliboutry, I97 I ; Paterson, 197I ; Harrison, 1972; Nye and Mae, 1972). Actual temperate glacier ice is a complex material with several components and phases, and it is subjected to non-hydrostatic stress. Pressure is only one of the effects determining phase equilibrium temperature, and consequently the common use of the expression "ice at the pressure melting point" is unfortunate. In fact, the temperature of a given temperate glacier is a property to be determined by experiment; to do so accurately has been the goal of the measurements described here. Evidently temperature is only part of the picture, and this experiment is part of a larger project to study other thermodynamically related properties of temperate glacier ice.

Temperature measurements were made in 1971 and 1972 at two sites in Blue Glacier, Mount Olympus, Washington, U.S.A. The lower site, at an elevation of about I $590 \mathrm{~m}$, was near the site of a previous bore hole deformation experiment by Shreve and Sharp (1970), who also considered the possible existence of thermal anomalies there. The upper site, about $700 \mathrm{~m}$ distant at an elevation of about I $700 \mathrm{~m}$, was near the site of previous borehole experiments by Harrison and Kamb (1973) and by Harrison (1972), who estimated glacier temperature from the rate of refreezing of water-filled bore holes. Usually the late summer snow line lies between these sites, but in 1971 and 1972 it was below both of them. The sites can be located on the map of Shreve and Sharp (1970, p. 67): The lower site, at the time of installation of the temperature sensors, was about $50 \mathrm{~m}$ up-glacier from the point marked s2, while the upper site was on the $1700 \mathrm{~m}$ contour about $190 \mathrm{~m}$ south-south-east from its point of intersection with the glacier margin.

\footnotetext{
* Present address: Geophysical Institute, University of Alaska, Fairbanks, Alaska 997or, U.S.A.
} 


\section{EXPERIMENTAL METHODS}

\section{(i) Thermistors and cables}

The measurements were made with glass-encapsulated thermistors of 3 ooo $\Omega$ nominal resistance at $0^{\circ} \mathrm{C}$. Each thermistor was mounted at the end of its own cable in such a way that there was no protuberance associated with it, thus permitting cable and thermistor to be easily melted free for calibration and future use at the end of the experiment. The procedure for mounting a thermistor was as follows: The vinyl sheath was pulled back from the end of the cable, and the thermistor mounted in the space made by cutting off three of the five conductors. The remaining space was filled with an elastomer, the sheath was slid back in place over the thermistor, and the end of the cable was sealed with vinyl cement.

Thermistor resistance was determined by connecting thermistor and a highly stable $3000 \Omega$ series resistor to a current source, and comparing voltages with a type of three-dial potentiometer commonly used for thermocouple measurements. Possible effects of thermistor heating and instrumental non-linearity were checked by varying the current, which was normally about $25 \mu \mathrm{A}$.

Each thermistor-cable assembly was calibrated in the laboratory in an ice bath prepared from distilled water and distilled-water ice, and at two temperatures (nominally -1 and $-2^{\circ} \mathrm{C}$ ) which were referred to the ice bath temperature with a thermometer which was graduated in o.or deg intervals and had calibration traceable to the U.S. National Bureau of Standards. A parabola was fitted to the resulting temperature-resistance relationship, although this is practically linear over the temperature range of the experiment ( 0.0 to $-0.2^{\circ} \mathrm{C}$ ). All calibrations were done at an ambient temperature of $0^{\circ} \mathrm{C}$, so that cable resistance was not appreciably different from its value in the glacier.

\section{(ii) Field procedure}

Bore holes, which were not cased, were made by $25 \mathrm{~mm}$ diameter electro-thermal drills capable of drilling about $8 \mathrm{~m} \mathrm{~h}^{-1}$. These were designed by Philip Taylor. On completion of a hole, the drill and drilling cable were recovered and replaced by a single thermistorcable assembly. It was felt that additional cables in the same hole might impede eventual cable recovery. To facilitate placement, a small weight was attached to each cable with thread which was easily broken for cable recovery.

All of the thermistors at the lower site, and all but one at the upper site, were calibrated again at time of placement by reading them when they were submerged to a depth of $1.5 \mathrm{~m}$ in the water that stood in all the bore holes. They were read again at their final position and then allowed to freeze in, which required roughly one week. Temperatures were read several times before the cables were recovered 2.3 to 13 months later. The cables were melted free for recovery by passing electrical current through a pair of conductors not connected to the thermistor, an operation requiring 5 or io $\mathrm{min}$. Immediately upon removal, each thermistorcable assembly from the lower site was recalibrated in an ice bath and a triple-point cell. Those from the upper site were recalibrated in an ice bath only.

The possibility of thermistor pressure sensitivity was investigated. Temperature in a waterfilled bore hole was measured at a water depth of $180 \mathrm{~m}$ with a standard thermistor-cable assembly, and simultaneously with a special one in which the thermistor was protected against pressure. No significant difference could be found.

\section{RESULTS AND ERRORS}

(i) Lower site

The temperature-depth relationship at the lower site on 9 October 197 I and II-I4 September 1972 is given in the first part of Table I and plotted in Figure I. The thermistors 
at this site were installed between 6 and 22 August $197 \mathrm{I}$ in a longitudinal line of bore holes about $0.7 \mathrm{~m}$ apart.

Ice-equivalent depths at time of measurement are given; in calculating these, the thickness of a surface layer of snow or firn ( $0.3 \mathrm{~m}$ in October 1971 and $0.6 \mathrm{~m}$ in September 1972 ) was replaced by its ice-equivalent thickness. The depth of a thermistor changes with time due to ablation at the surface and deformation of the ice. The effect of the latter was determined

TABle I. Glacier temperatures

\begin{tabular}{|c|c|c|c|}
\hline \multicolumn{4}{|c|}{ Lower site 9 October $197 \mathrm{I}$} \\
\hline $\begin{array}{c}\text { Depth } \\
\text { m }\end{array}$ & $\underset{{ }^{\circ} \mathrm{C}}{\text { Temperature }}$ & $\begin{array}{l}\text { Random } \\
\text { error } \\
\text { deg }\end{array}$ & $\begin{array}{c}\text { Systematic } \\
\text { error } \\
\text { deg }\end{array}$ \\
\hline 5.6 & -0.0215 & 0.0012 & 0.0018 \\
\hline 13.2 & -0.0278 & 0.0012 & 0.0018 \\
\hline 13.7 & -0.0275 & 0.0012 & 0.0018 \\
\hline 23.7 & -0.0321 & 0.0013 & 0.0018 \\
\hline $4^{8.7}$ & $-0.05^{22}$ & 0.0016 & 0.0018 \\
\hline 82.8 & $-0.075^{6}$ & 0.0020 & 0.0019 \\
\hline 118.2 & -0.1058 & 0.0022 & 0.0020 \\
\hline I 53.5 & -0.1303 & 0.0028 & 0.0021 \\
\hline 189.1 & -0.1534 & 0.0030 & 0.0022 \\
\hline
\end{tabular}

\begin{tabular}{|c|c|c|c|}
\hline \multicolumn{4}{|c|}{ Lower site II-I4 September 1972} \\
\hline $\begin{array}{c}\text { Depth } \\
\text { m }\end{array}$ & $\begin{array}{c}\text { Temperature } \\
{ }^{\circ} \mathrm{C}\end{array}$ & $\begin{array}{c}\text { Random } \\
\text { error } \\
\text { deg }\end{array}$ & $\begin{array}{c}\text { Systematic } \\
\text { error } \\
\text { deg }\end{array}$ \\
\hline 5.8 & -0.0244 & 0.0012 & 0.0015 \\
\hline I 3.4 & -0.0278 & 0.0012 & 0.0015 \\
\hline 13.9 & -0.0301 & 0.0012 & 0.0015 \\
\hline 24.0 & $-0.035^{I}$ & 0.0013 & 0.0016 \\
\hline 48.9 & -0.0575 & 0.0016 & 0.0016 \\
\hline $8_{3.2}$ & -0.08 Io & 0.0020 & 0.0017 \\
\hline 119.1 & -0.1131 & 0.0022 & 0.0018 \\
\hline I 55.3 & $-0.13^{82}$ & 0.0028 & 0.0019 \\
\hline 192.0 & -0.1611 & 0.0030 & 0.0020 \\
\hline
\end{tabular}

Upper site 7-8 October 1971

\begin{tabular}{|c|c|c|c|}
\hline $\begin{array}{c}\text { Depth } \\
\text { m }\end{array}$ & $\begin{array}{c}\text { Temperature } \\
{ }^{\circ} \mathrm{C}\end{array}$ & $\begin{array}{c}\text { Random } \\
\text { error } \\
\text { deg }\end{array}$ & $\begin{array}{c}\text { Systematic } \\
\text { error } \\
\text { deg }\end{array}$ \\
\hline 2.8 & +0.001 & 0.004 & 0.003 \\
\hline I 5.5 & -0.034 & 0.004 & 0.003 \\
\hline $35 \cdot 1$ & -0.045 & 0.004 & 0.003 \\
\hline $55 \cdot 9$ & -0.060 & 0.004 & 0.003 \\
\hline 76.1 & -0.072 & 0.004 & 0.003 \\
\hline
\end{tabular}

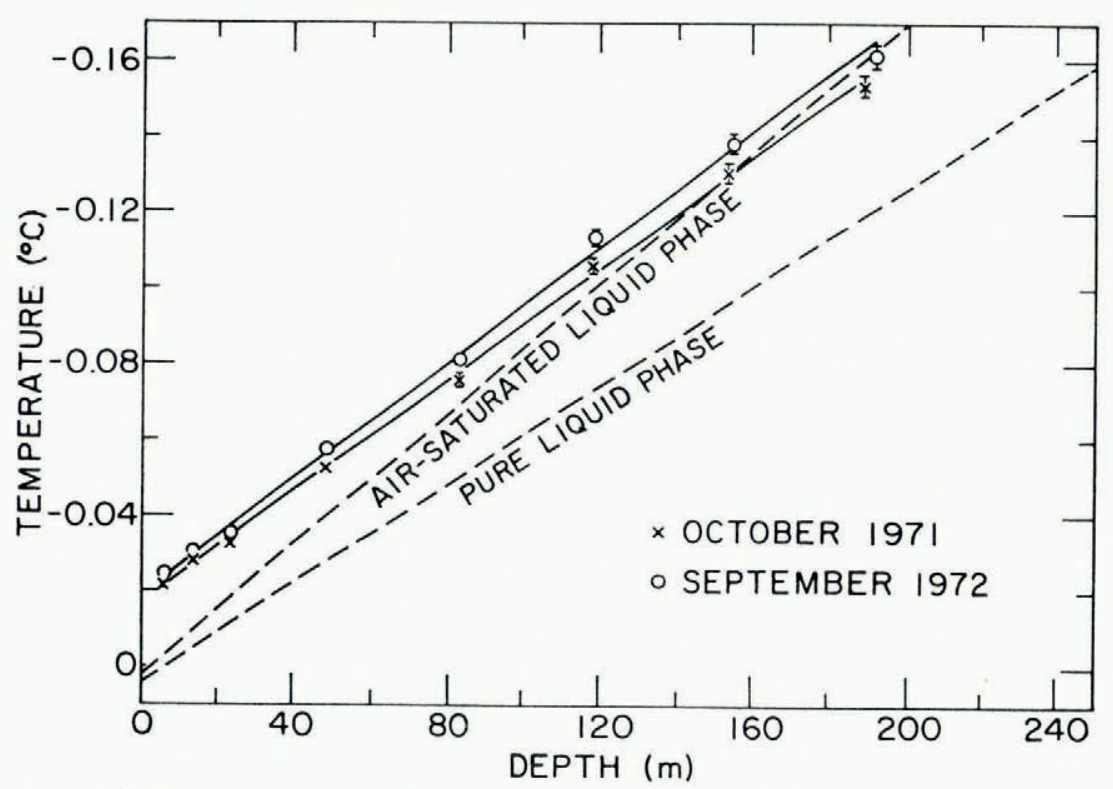

Fig. I. Temperature-depth relationship on two dates at the lower site, with random errors indicated. Typical systematic error is about o.oorg deg. The solid lines are least-squares straight-line fits to the data. Two models of temperate ice are indicated by the broken lines. Total depth is about $250 \mathrm{~m}$ (Corbató, 1965; Meier and others, 1974). 
from the observed stretching of the cables and the known shear strain-rate (Shreve and Sharp, 1970), and is discussed separately (Harrison, 1975). Motion of the thermistors parallel to the surface between the times of measurement varied from about $5^{2} \mathrm{~m}$ at the surface to about $37 \mathrm{~m}$ at a depth of $190 \mathrm{~m}$, as calculated from the data of Meier and others (1974), and of Shreve and Sharp (1970).

All uncertainties are expressed as standard deviations. An attempt has been made in Table I to distinguish between random and systematic errors, the latter being those that would have the same sign for all thermistors. Both these errors increase as temperatures become colder because of uncertainty in the slope of the temperature-resistance calibration curves. This is not significant at the warmer temperatures, where systematic errors are determined by two effects to be discussed in more detail; uncertainty in the calibration near $0^{\circ} \mathrm{C}$, and uncertainty in the temperature disturbance introduced by drilling.

A "best" calibration, to which all the temperatures were referred, was found for each thermistor by correcting its laboratory calibration by a small constant amount to give the best agreement among the three calibrations carried out near $0^{\circ} \mathrm{C}$ in the field. A comparison of all calibrations near $0^{\circ} \mathrm{C}$ is given in Table II, where the temperature of each calibration standard, measured relative to the "best" calibration, is averaged over the lower-site thermistors; standard deviations from this average are given. The calibration procedure does not favour any one of the temperature standards used in the field, but fortuitously gives the correct average temperature for the triple-point cell, which is the most reliable of them. The agreement of the other calibration standards with the triple-point cell is considered good, in view of some uncertainty in their exact temperatures. Thermistor calibration drift in the field, if any, is probably less than o.oor deg. This must be qualified in the case of the thermistor at $13.7^{-1} 3.9 \mathrm{~m}$ depth, which gave reasonable ice temperature readings, yet showed a large calibration change (o.or $3 \mathrm{deg}$ ) on removal. Inspection of the cable indicated damage that might have admitted water or permitted a large current to pass through the thermistor when the cable was melted free. This thermistor was omitted from the averages in Table II. The systematic error associated with the calibration near $0^{\circ} \mathrm{C}$ is estimated to be about o.oor $5 \mathrm{deg}$.

TAble II. Comparison of Calibrations near $0^{\circ} \mathrm{C}$ at THE lower site

Laboratory ice bath

Bore-hole water $1.5 \mathrm{~m}$ below water surface

Field ice bath

Triple-point cell

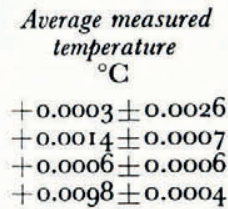

$$
\begin{gathered}
\text { Nominal } \\
\begin{array}{c}
\text { temperature* } \\
{ }^{\circ} \mathrm{C}
\end{array} \\
+0.0002 \\
+0.0004 \\
+0.0017 \\
+0.0098
\end{gathered}
$$

* The first three nominal temperatures were computed from the pressure at the thermistor, allow ing for both atmospheric pressure variation with altitude and immersion effects, and assuming the liquid phase to be air-saturated with respect to ambient atmospheric pressure. The triple-point temperature, by definition $+0.0100^{\circ} \mathrm{C}$, was corrected for the head of water in the triple-point cell.

A method for estimating the temperature disturbance introduced by drilling is discussed

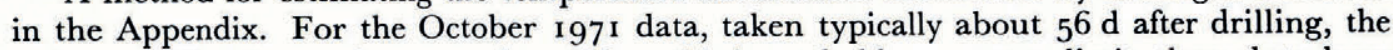
estimated disturbance is $0.0017 \mathrm{deg}$. Since this is probably an upper limit, these data have been corrected by half of this amount, and the rest included as a contribution to the systematic error. For the September 1972 data, taken typically $395 \mathrm{~d}$ after drilling, the estimated disturbance remaining is $0.0002 \mathrm{deg}$, which is negligible compared with the calibration errors. It appears that most of the difference between the October 1971 and September 1972 temperature data (Fig. I) is real, and not due to the drilling disturbance. Two factors would contribute to this: Temporal change in the temperature-depth relationship at a fixed location, and longitudinal motion of the thermistors (noted previously) through a longitudinal temperature gradient. Without further information their relative importance remains unknown. 


\section{(ii) Upper site}

The temperature-depth relationship at the upper site on 7-8 October $197 \mathrm{I}$ is given in the second part of Table I and plotted in Figure 2. The thermistors at this site were installed between $\mathrm{I}$ and 30 July $197 \mathrm{I}$ in bore holes arranged in an array with maximum dimension of about $30 \mathrm{~m}$.

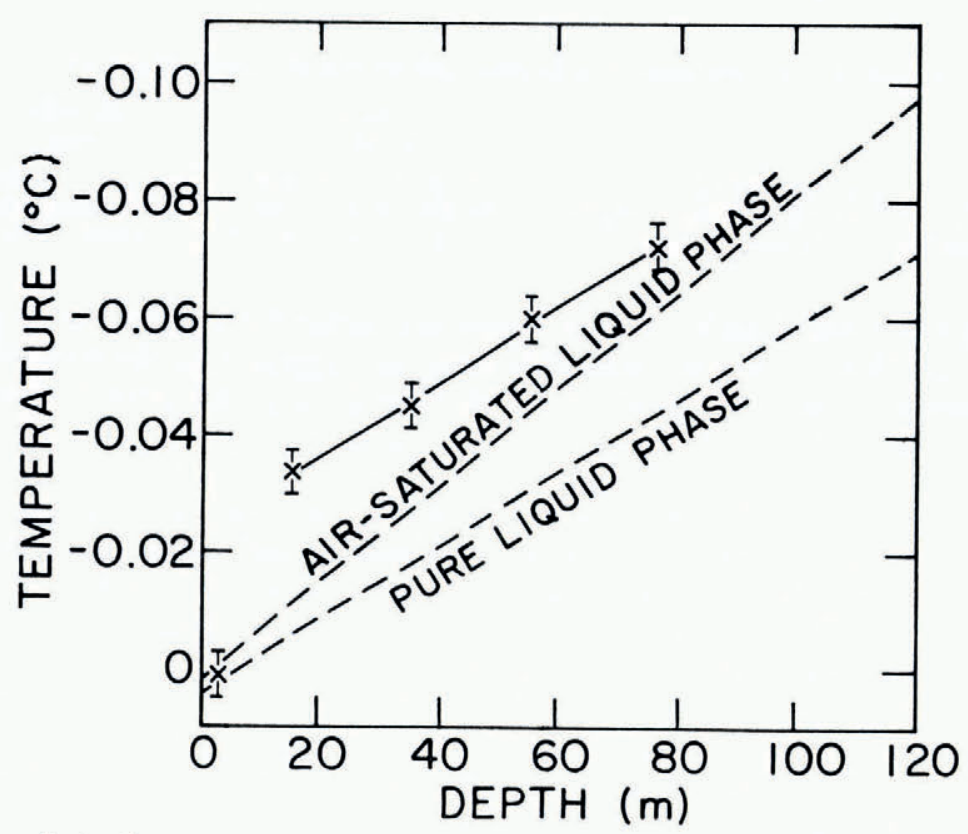

Fig. 2. Temperature-depth relationship at the upper site in October 1971 , with random errors indicated. Systematic error is about 0.003 deg. The lines have the same meaning as in Figure I. Total depth is about $120 \mathrm{~m}$.

The depths given are ice-equivalent depths. No depth correction for ice deformation was made, but this is small due to the rather short time (2.3 to 3.3 months) that the thermistors were in place. Surface motion is about $55 \mathrm{~m} \mathrm{a}^{-1}$ in this vicinity. The errors at this site are greater than those at the lower one, mainly because of lower instrumental sensitivity and lack of triple-point cell calibration. Uncertainty in the temperature disturbance introduced by drilling is dominated by calibration error.

\section{Discussion}

It is obvious in Figure $I$ that the temperature-depth relationship at the lower site is very nearly linear over the depth studied. The solid straight lines were fitted to the data by the method of least squares. A statistical analysis indicates that, given the errors in Table I, departures from linearity in the October 197 I data are not significant. This may not be true of the September 1972 data, but errors are not known well enough for a definite conclusion to be drawn. Figure 2 shows that except for the point at $2.8 \mathrm{~m}$ depth, the temperature-depth relationship is linear at the upper site also, although the errors are larger there. The solid line is the least-squares fit, made with the $2.8 \mathrm{~m}$ point deleted.

The parameters of the fitted straight lines and their errors are given in Table III. Assuming that linearity really holds, it is possible to estimate the errors in the temperature given by these straight lines. At the lower site these vary from about $0.0019 \mathrm{deg}$ at depths less than 
$50 \mathrm{~m}$ to about $0.0028 \mathrm{deg}$ at $190 \mathrm{~m}$ for the line fitted to the October $197 \mathrm{I}$ data, and from about 0.0016 deg to $0.0027 \mathrm{deg}$ for the September 1972 line. At the upper site these errors are typically about $0.004 \mathrm{deg}$, and as already noted, linearity breaks down near the surface. The distinction between random and systematic errors in the temperature data was taken into account in estimating the error of calculated quantities. Errors in depth were assumed to be relatively insignificant; this is probably valid.

TAble III. Parameters of Straight Lines fitted to temperature data

\begin{tabular}{|c|c|c|}
\hline & $\begin{array}{c}\text { Slope } \\
\operatorname{deg} \mathrm{m}^{-1}\end{array}$ & $\begin{array}{l}\text { Intercept } \\
\text { deg }\end{array}$ \\
\hline Lower site $\left\{\begin{array}{l}9 \text { October } 1971 \\
\text { I I }-14 \text { September } 1972\end{array}\right.$ & $\begin{array}{l}-(0.730 \pm 0.011) \times 10^{-3} \\
-(0.762 \pm 0.011) \times 10^{-3} \\
-(0.64+0.09) \times 10^{-3}\end{array}$ & $\begin{array}{l}-0.0170 \pm 0.0017 \\
-0.0188 \pm 0.0019 \\
-0.023 \pm 0.005\end{array}$ \\
\hline Upper site $7-8$ Óctober 197 I & $-(0.64 \pm 0.09) \times 10^{-3}$ & \\
\hline
\end{tabular}

The departure from linearity at the upper site indicated by the $2.8 \mathrm{~m}$ point may be related to the fact that the firn is permeable there, as suggested by the level of water in this bore hole, which was about $\mathrm{I} \mathrm{m}$ lower than the thermistor at the time of cable installation. The bore hole was carefully filled with snow after installation, and the cable was frozen in when the thermistor was read.

It has been suggested by Paterson (1972) that the ablation areas of most temperate glaciers, including Blue Glacier, may have a near-surface layer considerably colder than $0^{\circ} \mathrm{C}$. The data from the lower site indicate that if such a layer exists there, it is thinner than $5 \mathrm{~m}$. Since no tendency was noted for water-filled bore holes to refreeze particularly rapidly at depths less than this, it is doubtful that such a cold layer exists at all. As already noted, the lower site is normally in the ablation area, but it was covered with a thin layer of snow or firn during the course of the experiment. Since this layer was wet at the times of measurement, its temperature was probably very close to $0^{\circ} \mathrm{C}$, and thus similar to the $2.8 \mathrm{~m}$ temperature recorded at the upper site.

The question of temporal change in temperature was raised in the last section, and some additional information is available. A few measurements made on 23 August 1971 at the lower site and on 2 and 23 August $197 \mathrm{I}$ at the upper site indicated that the temperaturedepth relationships were probably not significantly different from their October 197 I values, considering the possible temperature disturbance due to drilling. This suggests that at least during the latter part of the summer, temperature changes, if any, were of the order of o.oor deg rather than, say, o.or deg.

The data can be compared with the predictions of some simple temperature models. The line labelled "pure liquid phase" in Figures $\mathrm{I}$ and 2 results from the following assumptions: (1) No impurities are present. (2) Temperature is not significantly influenced by the curvature of the ice-water interfaces. (3) The pressure in the liquid phase determines the equilibrium temperature (see Kamb, 196I). (4) The pressure in the liquid phase is equal to the mean compressive stress in the ice. (5) This ice stress $p_{\mathrm{i}}$ is given by

$$
p_{\mathrm{i}}=\rho g h \cos ^{2} \alpha
$$

(Nye, 1953) where $\rho$ is the density of glacier ice (about $0.90 \mathrm{Mg} \mathrm{m}^{-3}$ ), $h$ is the vertical depth, $g$ is the gravitational acceleration, and $\alpha$ is the surface slope (about $4.8^{\circ}$ at the lower site and $12^{\circ}$ at the upper). (6) The change of equilibrium temperature with pressure is a constant given by $-0.0074^{2} \mathrm{deg} \mathrm{bar}^{-1}$. In this model the effect of reduced atmospheric pressure at the elevation of the measurements raises the temperature at the surface from +0.0024 to $+0.0039^{\circ} \mathrm{C}$.

The line labelled "air-saturated liquid phase" in Figures I and 2 results from a similar set of assumptions except that the liquid phase is assumed to be saturated with the impurity 
air. In this case the change of the equilibrium temperature with pressure is $-0.0098 \mathrm{deg}$ $\mathrm{bar}^{-1}$, and is more rapid than in the previous model because the solubility of the air increases with pressure. The surface temperature in this model is $+0.0019^{\circ} \mathrm{C}$. Slightly different models, assuming pressure in the liquid phase to be equal to maximum principal ice stress, are considered by Harrison (1972, p. 24).

It is evident in Figures 2 and 3 that neither of these simple models describes the actual temperature. The failure of the pure liquid phase model is particularly obvious. This failure was also observed by Paterson (1971) and by Harrison (1972) on the basis of data with about an order of magnitude lower accuracy.* In the latter experiment, located at the upper site of the present one, temperatures estimated from the rate of freezing of bore holes are slightly too cold due to the high effective heat capacity of temperate ice (Harrison, 1972, p. 27).

Other properties of the ice such as liquid-water and impurity content, grain and vein geometry, and bubble pressure have been studied. A more complete discussion of temperature will be postponed until these results are presented.

\section{Acknowledgements}

I am grateful for the assistance in the field and the suggestions of persons too numerous to mention individually. The National Science Foundation provided the principal financial support under grants GU 2655 and GA 28544, and the National Park Service gave permission for work on the glacier. The preparation of this paper was supported by State of Alaska funds.

\section{MS. received 19 March 1974 and in revised form 21 May 1974}

\section{REFERENCES}

Bullard, E. C. 1947. The time necessary for a borehole to attain temperature equilibrium. Monthly Notices of the Royal Astronomical Society. Geophysical Supplement, Vol. 5, No. 5, p. $127-30$.

Carslaw, H. S., and Jaeger, J. C. 1959. Conduction of heat in solids. Second edition. Oxford, Clarendon Press.

Corbató, C. E. 1965. Thickness and basal configuration of lower Blue Glacier, Washington, determined by gravimetry. Fournal of Glaciology, Vol. 5, No. 41, p. 637-50.

Harrison, W. D. 1972. Temperature of a temperate glacier. Journal of Glaciology, Vol. 1 1, No. 61, p. I5-29.

Harrison, W. D. 1975. A measurement of surface-perpendicular strain-rate in a glacier. Journal of Glaciology, Vol. ${ }_{14}$, No. 70, p. 31-37.

Harrison, W. D., and Kamb, W. B. 1973. Glacier bore-hole photography. Journal of Glaciology, Vol. 12, No. 64, p. $129-37$.

Kamb, W. B. ${ }^{1961}$. The thermodynamic theory of nonhydrostatically stressed solids. Journal of Geophysical Research, Vol. 66, No. 1, p. 259-71.

Lachenbruch, A. H., and Brewer, M. C. 1959. Dissipation of the temperature effect of drilling a well in Arctic Alaska. U.S. Geological Survey. Bulletin, 1083-C, p. 73-109.

Lliboutry, L. A. 1971. Permeability, brine content and temperature of temperate ice. Fournal of Glaciology, Vol. 10, No. 58, p. $15^{-29}$.

Meier, M. F., and others. 1974. Flow of Blue Glacier, Olympic Mountains, Washington, U.S.A., by M. F. Meier, W. B. Kamb, C. R. Allen and R. P. Sharp. Journal of Glaciology, Vol. 13, No. 68, p. 187-212.

Nye, J. F. 1953. The flow law of ice from measurements in glacier tunnels, laboratory experiments and the Jungfraufirn borehole experiment. Proceedings of the Royal Society of London, Ser. A, Vol. 219 , No. 1139 , p. 477-89.

Nye, J. F., and Frank, F. C. I973. Hydrology of the intergranular veins in a temperate glacier. Union Géodésique et Géophysique Internationale. Association Internationale d'Hydrologie Scientifique. Commission de Neiges et Glaces. Symposium on the Hydrology of Glaciers, Cambridge, 7-13 September 1969, organized by the Glaciological Society, p. $157-61$.

Nye, J. F., and Mae, S. 1972. The effect of non-hydrostatic stress on intergranular water veins and lenses in ice. fournal of Glaciology, Vol. i r, No. 61, p. 81-101.

Paterson, W. S. B. 1971. Temperature measurements in Athabasca Glacier, Alberta, Canada. Journal of Glaciology, Vol. 10, No. 6o, p. 339-49.

* A similar conclusion by Hess and Blümcke, based on measurements made near the turn of the century, is alluded to by Renaud ([1952], p. 207). 
Paterson, W. S. B. 1972. Temperature distribution in the upper layers of the ablation area of Athabasca Glacier, Alberta, ( Camada. Journal of Glaciology, Vol. 11 , No. 61, p. 31-41.

Renaud, A. [1952.] Nouvelle contribution à l'étude du grain de glacier. Union Géodésique et Géophysique Internationale. Association Internationale d'Hydrologie Scientifique. Assemblée générale de Bruxelles, 1951 , Tom. 1, p. 206-1 1. Shreve, R. 1.., and Sharp, R. P. 1970. Internal deformation and thermal anomalies in lower Blue Glacier, Mount Olympus, Washington, U.S.A. Journal of Glaciology, Vol. 9, No. 55, p. 65-86.

\section{APPENDIX}

The drilling of any hole introduces heat, causing a temperature disturbance which persists after drilling is completed. Often it is fairly straightforward to estimate the magnitude of this effect (Bullard, 1947; Lachenbruch and Brewer, 1959) but in temperate ice a difficulty arises: Although the thermal conductivity of temperate ice is about the same as that of cold ice, its effective heat capacity is temperature dependent and larger than that of cold ice (Harrison, 1972). We neglect this difficulty for the moment.

If a line source in a material of thermal conductivity $K$ emits $Q$ units of heat per unit length at time zero, the temperature disturbance $\Delta T$ on the line at time $t$ is

$$
\Delta T=\frac{Q}{4^{\pi K t}}
$$

(Carslaw and Jaeger, 1959). In this experiment $Q$ is the latent heat released during the refreezing of a bore hole with radius of about i $5 \mathrm{~mm}$, and $Q / 4 \pi K$ is about $0.094 \mathrm{deg} \mathrm{d}$. The expression will hold only for times significantly greater than one week, which is the time required for refreezing.

Because it does not contain the heat capacity, there is hope that this expression may be useful even in temperate ice. But since it is a solution of a differential equation which does not take into account the temperature dependence of the effective heat capacity, this is not obviously true. A slightly more elaborate analysis using methods similar to those of Lachenbruch and Brewer (1959) indicates that the expression would work well in cold ice, but in temperate ice the disturbance probably dies out faster because of the high effective heat capacity. We conclude that since the expression probably gives an upper limit to the temperature disturbance, it is useful. 